Bangladesh J. Bot. 40(2): 177-184, 2011 (December)

\title{
ECOLOGICAL RESPONSE OF SOME IRIS L. TAXA (IRIDACEAE) IN TURKEY
}

\author{
Nezahat Kandemir*, Ali Çelik ${ }^{1}$ and Abdulkadir Sürücü² \\ Department of Biology, Education Faculty, Amasya University, Amasya-Turkey
}

Key words: Iris taxa, Endemic, Rare, Ecological properties, Relationship

\begin{abstract}
Ecological relationships of some Iris taxa belonging to subgenera Hermodactyloides (I. danfordiae, I. histrio subsp. aintabensis, I. histrio subsp. histrio, I. reticulata, I. bakeriana, I. pamphylica) and Scorpiris (I. aucheri and I. persica) have been compared and relationships between taxa have been determined. These taxa are geophytes and flower in Spring. I. danfordiae, I. pamphylica and subsp. aintabensis are endemic to Turkey. I. reticulata and I. persica have widespread distribution while I. aucheri, subsp. aintabensis, subsp. histrio, I. pamphylica and I. bakeriana have restricted distribution in Turkey. Soil samples of the taxa were collected during flowering periods and physical and chemical properties (texture class, total salinity \%, $\mathrm{pH}$, $\mathrm{CaCO}_{3} \%$, organic matter \%, $\mathrm{N} \%, \mathrm{P}$ kg/da, $\mathrm{K} \mathrm{kg} / \mathrm{da}, \mathrm{Ca}, \mathrm{Mg}, \mathrm{Mn}, \mathrm{Cu}, \mathrm{Fe}$ and $\mathrm{Zn} \mathrm{ppm}$ ) were determined. The correlations between the soil analyses and taxa were evaluated using regression analysis. The $\mathrm{P}$ and $\mathrm{CaCO}_{3}$ values were found to be more effective than the other soil factors in the distributions of investigated taxa.
\end{abstract}

\section{Introduction}

Iris L. is one of the largest genus of Iridaceae family and comprises over 300 species in the world. They have been distributed in the Northern Hemisphere (Yu et al. 2009). Iris species have been used as ornamental plants in vegetative landscape of the parks and gardens in many countries since ancient times because of very beautiful and colorful flowers (specially in rock garden $I$. histrio and I. reticulata). I. histrioides (Wilson) Arnott, I. nectarifera Güner, I. pamphylica Hedge, I. galatica Siehe and I. persica are consumed as food in rural areas. I. persica is one of the symbols of Nevrus Festival which resembles as the coming of Spring (Kandemir and Engin 1998, 2000a, Anon. 2010).

The investigated taxa belong to Hermodactyloides and Scorpiris subgenera. The species of these two subgenera distribute naturally in Turkey (Güner and Peşmen 1980, Güner 1980, Christensen and Akpulat 2004, Güner and Duman 2007). In the distribution of species of Hermodactyloides subgenus Anatolia Diagonal plays an important role. Whereas the species of Scorpiris subgenus are distributed on both sides of Anatolia Diagonal (Güner 1980), I. danfordiae is found in the west of Anatolia Diagonal from north to south, I. histrio is at the south part, I. pamphylica is in vicinity of Antalya from the Toros Mountains to the west, and I. reticulata and I. bakeriana are in the east of Anatolia Diagonal. I. reticulata and I. persica occupied the largest area. However, subsp. aintabensis, subsp. histrio, I. aucheri, I. bakeriana and I. pamphylica are rare species and they are only known in the Southern part of Turkey (except I. aucheri).

Geophytic plants have interesting ecophysiological characteristics. They pass a long winter and drought period with under ground parts, so, this redistribution is important for the economical use of macroelements. In addition, they have interesting phenological properties with respect to

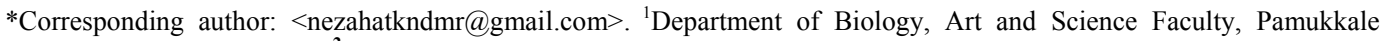
University, Denizli-Turkey. ${ }^{2}$ Department of Soil Science and Plant Nutrition, Agriculture Faculty, Bingöl University, Bingöl-Turkey. 
spring or autumn of flowering time (Kutbay 1999). Therefore, it is necessary to know the ecological features of these taxa to grow and culture them easily and quickly. The purpose of this paper is to compare the ecological response of some Iris taxa and their relationships with soil properties.

\section{Materials and Methods}

Plant samples were collected from different locations between 2008 and 2010. Taxonomic description of the samples were made according to Mathew $(1984,1989)$ and Güner and Peşmen (1980). The distribution areas of the taxa were coded as A, B, C, D, E, F, G and H (Table 1). Soil samples $(0-20 \mathrm{~cm})$ were collected during generative growth period. Analysis of soil samples were

Table 1. The localities of collection of Iris taxa in Turkey.

\begin{tabular}{|c|c|}
\hline $\begin{array}{l}\text { Locality } \\
\text { code }\end{array}$ & Description of locations \\
\hline & I. danfordiae (Baker) Boiss. \\
\hline A1 & Amasya: Boğa Village-Kaşka mezrası, near culture areas, 750 m., 22 February 2009, Kandemir, 427. \\
\hline A2 & $\begin{array}{l}\text { Ordu: Mesudiye-Gölköy, Muzamana village vicinity Quercus shrub, rocky areas, } 1100 \text { m., } 6 \text { Mach 2009, } \\
\text { Kandemir, } 428 \text {. }\end{array}$ \\
\hline \multirow[t]{2}{*}{ A3 } & $\begin{array}{l}\text { C5 Niğde: Ulukışla-Aktoprak Village, Gobatdere areas, Abies cilicica forest, metamorphic areas, } 1800 \text { m., } 8 \\
\text { March } 2009 \text {, Kandemir, } 429 \text {. }\end{array}$ \\
\hline & I. bakeriana Foster \\
\hline B1 & Gaziantep: Yeşilce Village-Sof Mountain, Quercus forest, 1200 m., 10 March 2009, Kandemir, 434 \\
\hline \multirow[t]{2}{*}{$\mathrm{B} 2$} & $\begin{array}{l}\text { Mardin: Savur-Pınardere Village, Menzeli areas, Quercus shrub calcareous areas, } 900 \text { m., } 20 \text { March 2009, } \\
\text { Kandemir, } 435 .\end{array}$ \\
\hline & I. histrio Reichb. subsp. histrio Mathew \\
\hline $\mathrm{C} 1$ & Gaziantep: Islahiye-Fevzipaşa, Nur Mountain, scrub areas, 600-800 m., 10 March 2009, Kandemir, 432. \\
\hline \multirow[t]{2}{*}{$\mathrm{C} 2$} & $\begin{array}{l}\text { Mersin: Silifke-Uzuncaburç, Delikılıç place, scrub and vineyard, calcareous rocky, } 1150 \mathrm{~m} \text {., } 12 \text { March } \\
\text { 2009, Kandemir, } 433 \text {. }\end{array}$ \\
\hline & I. histrio subsp. aintabensis (Baker) Mathew \\
\hline D1 & Gaziantep: Yeșilce Village-Sof Mountain, Quercus forest, 1200 m., 12 March 2009, Kandemir, 430. \\
\hline \multirow[t]{2}{*}{$\mathrm{D} 2$} & $\begin{array}{l}\text { Gaziantep: Bahçearası-Acarobası Village, Kesmeliburun areas, scrub and calcareous rocky, } 1100 \text { m., } 10 \\
\text { March 2009, Kandemir, } 431 .\end{array}$ \\
\hline & I. reticulata M. Bieb. \\
\hline E1 & Gaziantep: Yeşilce village-Sof Mountain, Quercus forest, 1000 m., 10 March 2009, Kandemir, 436. \\
\hline E2 & Urfa: Karaca Mountain, open areas, 1550 m., 28 March 2009, Kandemir, 437. \\
\hline E3 & Urfa: Siverek-Sakaltutan Plateau vicinity. 1400 m., 20 May 2009, Kandemir, 438. \\
\hline $\mathrm{E} 4$ & $\begin{array}{c}\text { Maraş: Göksun-Acalmak Cennet Stream, Abies forest, } 1800 \text { m., } 2 \text { April 2009, Kandemir, } 439 . \\
\text { I. pamphylica Hedge }\end{array}$ \\
\hline F1 & $\begin{array}{l}\text { Antalya: Manavgat-Akseki, Fersin Village, Çakılcık valley, south slope, rocky areas, } 850 \text { m., } 14 \text { March } \\
2009 \text {, Kandemir, } 440 \text {. }\end{array}$ \\
\hline \multirow[t]{2}{*}{ F2 } & $\begin{array}{l}\text { Mersin: Findık Pınarı Platae-Akarca güzlesi, road side and open forest areas, 900-100 m., } 8 \text { April } 2009 \text {, } \\
\text { Kandemir, } 441 .\end{array}$ \\
\hline & I. aucheri (Baker) Sealy \\
\hline G1 & Gaziantep: Ișiklı Village-Sof Mountain, rocky areas, 1200 m., 10 April 2009, Kandemir, 442. \\
\hline $\mathrm{G} 2$ & Urfa: Bilecik to Sorik, culture areas, 700 m., 11 April 2009, Kandemir, 443. \\
\hline G3 & Urfa: Karaca Mountain ,volcanic meadowland, 1100 m., 11 April 2009, Kandemir, 444. \\
\hline G4 & Maraş: Türkoğlu-Uzunsöğüt Village vicinity, shrub areas, 500-650 m., 10 April 2009, Kandemir, 445. \\
\hline & I. persica L. \\
\hline H1 & Amasya: Kışlacık Village-TV station vicinity, 1000-1100 m., 1 March 2009, Kandemir, 446. \\
\hline $\mathrm{H} 2$ & Tokat: Yıldızeli-Camlıbel Pass, 1500 m., 8 March 2009, 447. \\
\hline $\mathrm{H} 3$ & Sivas: Sușehri to Gölköy vicinity, Crataegus woody bottom, 900 m., 8 March 2009, Kandemir, 448. \\
\hline $\mathrm{H} 4$ & Kayseri: Pınarbaşı-Gürün Kızılçevik, 1650 m., 9 March 2009, Kandemir, 449. \\
\hline H5 & Kilis: Kilis to Islahiye, calcareous shrub areas, $550 \mathrm{~m} ., 11$ March 2009, Kandemir, 450. \\
\hline H6 & Gaziantep: Gaziantep University Campus, shrub areas, 500 m., 11 March 2009, Kandemir, 451. \\
\hline H7 & Gaziantep:Yeşilce village-Sof Mountain, Quercus forest, 1000 m., 10 March 2009, Kandemir, 452. \\
\hline $\mathrm{H} 8$ & Urfa: Halfeti-Rumkale, rocky slopes near Firat N, 500 m., 25 March 2009, Kandemir, 453. \\
\hline H9 & Urfa: Birecik- Mezra, steppe areas, 800 m., 25 March 2009, Kandemir, 454. \\
\hline
\end{tabular}


made in the soil analyses laboratory of Southeastern Anatolian Project Institution of Soil-Water Resources and Agricultural Research Directorate. Soil texture was determined by Bouyoucus hydrometer method, total salinity, calcium carbonate $\left(\mathrm{CaCO}_{3}\right)$ and $\mathrm{pH}$ were measured by Conductivity Bridge apparatus, Scheibler Calcimeter and Beckman pH meter, respectively (Kaçar 1996). Nitrogen, phosphorus, potassium, organic matter and microelements contents of the soil samples were analyzed by micro-Kjeldahl apparatus, ammonium-molybdate-stannous chloride, flame photometer and the Walkley-Black and DTPA (Diethylenetriaminepentaacetic acid) $+\mathrm{CaCl}_{2}$ + TEAL Triethanolomine) methods, respectively (Kaçar 1996). Some species of Hermodactyloides and Scorpiris subgenera have great interspecific variations in morphology (particularly I. reticulata, I. bakeriana, I. histrio and I. persica), their taxonomic status and interspecific relationships are still disputed. That is why the regression analysis were used in the soil analysis results of these species.

\section{Results and Discussion}

All the investigated taxa prefer non saline and slightly saline soils (Table 2). I. danfordiae, subsp. aintabensis, I. bakeriana, I. reticulata, I. aucheri and I. persica were found to grow in clayey-loamy soils. Subsp. histrio, I. danfordiae and I. pamphylica grow in loamy soils. Most species are extremely distributed in loamy soils where drainage is good. Also, I. aucheri and $I$. persica prefer clayey soils. It has been observed that I. histrioides (Kandemir and Engin 2000 a), I. pseudacorus L. (Engin et al. 1998), I. galatica (Kandemir and Engin 2000 b), I. sari Schott ex Baker (Kandemir 2003), Crocus pestalozzae Boiss. (Kandemir 2009) and some Crocus taxa (Şık and Candan 2009) prefer clayey-loamy and loamy soils.

While I. danfordiae, subsp. aintabensis, subsp. histrio, I. pamphylica, I. aucheri and I. persica prefer soils with moderate level of $\mathrm{CaCO}_{3}$, subsp. aintabensis, I. bakeriana, I. reticulata and I. persica prefer soils with low level of $\mathrm{CaCO}_{3}$. Species such as I. pseudacorus (Engin et al. 1998), I. histrioides (Kandemir and Engin 2000a), I. taochia Woronow ex Grossh. (Kandemir 2006), C. pestalozzae (Kandemir 2009) and some Iris species (Malyer 1983) have been reported to prefer soils with moderate level of $\mathrm{CaCO}_{3}$ whereas I. danfordiae, subsp. aintabensis, I. reticulata, I. aucheri and I. persica grow in slightly alkaline soils, I. danfordiae, subsp. histrio, I. aucheri and I. persica grow in well moderate level alkaline soils. I. taochia (Kandemir 2006), I. nectarifera (Kandemir and Engin 1998), I. galatica (Kandemir and Engin 2000b), Alkanna haussknechtii Bornm. (Kandemir and Cansaran 2010) and I. histrioides (Kandemir and Engin 2000a) grow in slightly alkaline soils, as do I. danfordiae, subsp. aintabensis, I. reticulata, I. aucheri and I. persica. However, I. bakeriana, I. reticulata, I. persica and I. pamphylica prefer neutral soils. In contrast, I. aucheri and I. persica prefer slightly acidic soils. It has been reported that $C$. pestalozzae (Kandemir 2009), I. sari (Kandemir 2003) and some Crocus taxa (Satıl and Selvi 2007) prefer slightly acidic soils.

The investigated taxa (except I. persica) grow well in soils containings moderate to rich organic matter. I. persica prefers to grow in soils having very rich organic matter. I. danfordiae, subsp. aintabensis, subsp. histrio, I. bakeriana and I. persica distribute well in soils with moderate to rich nitrogen containing soils. On the other hand, I. reticulata, I. aucheri, I. pamphylica and I. persica proper soils rich in nitrogen. I. pseudacorus (Engin et al. 1998), I. galatica (Kandemir and Engin 2000 b), I. histrioides (Kandemir and Engin 2000 a), I. taochia (Kandemir 2006), A. haussknechtii (Kandemir and Cansaran 2010), I. sari (Kandemir 2003) and C. pestalozzae (Kandemir 2009) grow in rich soils in respect of organic matter and nitrogen. $21 \%$ of all soils in Turkey have very limited amount of nitrogen (Boşgelmez et al. 2001). It can be said that the Iris taxa grow in soil with too little nitrogen. But, the investigated taxa have not been observed in soils deficient in N. All the investigated taxa grow well (except subsp. histrio) are usually sufficient in 
$\mathrm{P}$ and $\mathrm{K}$ content. But, the $\mathrm{K}$ content of the soil samples where subsp. histrio is distributed was at insufficient levels (Table 2). It has been reported by various researchers that taxa such as $I$. nectarifera (Kandemir and Engin 1998), I. pseudacorus (Engin et al. 1998), I. histrioides, I. galatica (Kandemir and Engin 2000 a, b), I. sari (Kandemir 2003), I. taochia (Kandemir 2006), C. pestalozzae (Kandemir 2009) and some Crocus taxa (Işık and Candan 2009) prefer soils with sufficient potassium. The P content of soils where C. pestalozzae (Kandemir 2009), some Crocus taxa (Satıl and Selvi 2007, Işık and Candan 2009) and I. histroides (Kandemir and Engin 2000a) are distributed at sufficient levels. However, in previously ecologic investigations some Iris taxa have been enumerated in soils of sufficient P (Kandemir and Engin 2000a,b, Kandemir 2003). This state may occur due to phloem-immobile $\mathrm{P}$ and insoluable $\mathrm{P}$ in soils. From the Table 2, it is seen that the amount of microelements are satisfactory in all of the soil samples, except $\mathrm{Zn}$ in $\mathrm{C} 2$, G4, H1, H3 and H5 localities. Iş1k and Candan (2009) have reported that the amount of microelements of soils where some Crocus taxa grow, are generally enough.

Table 2. Physical and chemical properties of soil from different localities.

\begin{tabular}{|c|c|c|c|c|c|c|c|}
\hline Locality code & Texture & $\begin{array}{l}\text { Salinity } \\
(\mathrm{EC})(\%)\end{array}$ & $\begin{array}{c}\mathrm{CaCO}_{3} \\
(\%)\end{array}$ & $\mathrm{pH}$ & $\begin{array}{c}\text { Organic } \\
\text { matter }(\%)\end{array}$ & $\begin{array}{c}\mathrm{N} \\
(\%)\end{array}$ & $\begin{array}{c}\mathrm{P}_{2} \mathrm{O}_{5} \\
(\mathrm{~kg} / \mathrm{da})\end{array}$ \\
\hline A1 & Clayey-loamy & 0.947 & 14.80 & 7.94 & 1.31 & 0.059 & 5.76 \\
\hline $\mathrm{A} 2$ & Clayey-loamy & 0.961 & 5.70 & 7.75 & 2.61 & 0.174 & 15.33 \\
\hline A3 & Loamy-calcareous & 1.174 & 6.0 & 7.67 & 3.05 & 0.064 & 17.13 \\
\hline Mean \pm Sd & - & $1.03 \pm 0.12$ & $8.86 \pm 5.22$ & $7.78 \pm 0.13$ & $2.32 \pm 0.90$ & $0.09 \pm 0.06$ & $12.7 \pm 6.11$ \\
\hline B1 & Clayey-loamy & 0.557 & 1.50 & 7.32 & 1.89 & 0.156 & 25.33 \\
\hline B2 & Clayey-loamy & 0.167 & 1.47 & 6.96 & 2.20 & 0.127 & 26.17 \\
\hline Mean \pm Sd & - & $0.36 \pm 0.27$ & $1.48 \pm 0.02$ & $7.14 \pm 0.25$ & $2.04 \pm 0.21$ & $0.14 \pm 0.02$ & $25.7 \pm 0.59$ \\
\hline $\mathrm{C} 1$ & loamy & 0.293 & 10.20 & 7.70 & 1.74 & 0.121 & 2.06 \\
\hline $\mathrm{C} 2$ & loamy & 0.389 & 12.90 & 7.97 & 1.45 & 0.061 & 2.14 \\
\hline Mean \pm Sd & - & $0.34 \pm 0.06$ & $11.5 \pm 1.90$ & $7.83 \pm 0.19$ & $1.59 \pm 0.20$ & $0.09 \pm 0.04$ & $2.10 \pm 0.05$ \\
\hline D1 & Clayey-loamy & 0.557 & 1.50 & 7.32 & 1.89 & 0.156 & 25.33 \\
\hline D2 & Clayey-loamy & 0.623 & 2.50 & 7.61 & 2.47 & 0.057 & 26.73 \\
\hline Mean \pm Sd & - & $0.5 \pm 0.04$ & $2.0 \pm 0.70$ & $7.46 \pm 0.20$ & $2.18 \pm 0.41$ & $0.10 \pm 0.07$ & $26.0 \pm 0.98$ \\
\hline E1 & Clayey-loamy & 0.557 & 1.50 & 7.32 & 1.89 & 0.156 & 25.33 \\
\hline E2 & Clayey-loamy & 0.742 & 2.28 & 7.81 & 1.36 & 2.65 & 15.02 \\
\hline E3 & Clayey-loam & 0.586 & 1.96 & 6.90 & 2.25 & 3.07 & 24.16 \\
\hline E4 & Clayey-loam & 0.420 & 1.82 & 6.90 & 2.18 & 2.91 & 22.53 \\
\hline Mean \pm Sd & - & $0.57 \pm 0.13$ & $1.89 \pm 0.32$ & $7.23 \pm 0.43$ & $1.92 \pm 0.40$ & $2.19 \pm 1.37$ & $21.7 \pm 4.63$ \\
\hline $\mathrm{F} 1$ & loamy & 0.23 & 2.60 & 7.35 & 4.12 & 4.50 & 5.20 \\
\hline F2 & loamy & 0.41 & 3.05 & 7.60 & 3.80 & 3.55 & 6.75 \\
\hline Mean \pm Sd & - & $0.32 \pm 0.13$ & $2.82 \pm 0.31$ & $7.48 \pm 0.17$ & $3.96 \pm 0.22$ & $4.03 \pm 0.67$ & $5.98 \pm 1.09$ \\
\hline G1 & Clayey-loamy & 0.653 & 2.20 & 7.61 & 3.80 & 2.30 & 6.89 \\
\hline G2 & clayey & 0.431 & 9.2 & 7.85 & 1.33 & 2.80 & 5.28 \\
\hline G3 & Clayey -loam & 0.328 & 4.39 & 6.45 & 2.65 & 5.32 & 6.32 \\
\hline G4 & clayey-loamy & 0.671 & 4.40 & 7.83 & 1.60 & 3.94 & 4.12 \\
\hline Mean \pm Sd & - & $0.52 \pm 0.16$ & $5.04 \pm 2.95$ & $7.43 \pm 0.66$ & $2.34 \pm 1.12$ & $3.59 \pm 1.34$ & $5.65 \pm 1.21$ \\
\hline $\mathrm{H} 1$ & clayey & 0.503 & 2.65 & 6.32 & 3.05 & 0.177 & 21.81 \\
\hline $\mathrm{H} 2$ & loamy & 0.245 & 1.69 & 6.77 & 2.80 & 1.86 & 18.56 \\
\hline H3 & Clayey-loamy & 0.229 & 1.50 & 6.45 & 1.87 & 0.071 & 25.33 \\
\hline $\mathrm{H} 4$ & Clayey-loam & 0.325 & 2.5 & 6.78 & 4.56 & 1.38 & 17.56 \\
\hline H5 & Clayey- & 0.829 & 14.80 & 7.98 & 1.89 & 0.061 & 15.43 \\
\hline H6 & Clayey-loamy & 0.942 & 28.10 & 7.97 & 2.50 & 1.25 & 12.65 \\
\hline $\mathrm{H} 7$ & Clayey-loam & 0.557 & 14.80 & 7.77 & 1.89 & 0.156 & 14.50 \\
\hline H8 & Clayey & 0.512 & 28.8 & 7.83 & 1.30 & 0.168 & 10.16 \\
\hline H9 & Clayey-loamy & 1.011 & 10.6 & 7.61 & 5.17 & 1.28 & 12.80 \\
\hline Mean \pm Sd & - & $0.57 \pm 0.29$ & $11.7 \pm 10.9$ & $7.38 \pm 0.58$ & $2.78 \pm 1.30$ & $0.87 \pm 0.74$ & $18.2 \pm 4.87$ \\
\hline
\end{tabular}


Table contd

\begin{tabular}{|c|c|c|c|c|c|c|c|}
\hline Locality code & $\begin{array}{c}\mathrm{K}_{2} \mathrm{O} \\
(\mathrm{kg} / \mathrm{da})\end{array}$ & $\begin{array}{c}\mathrm{Ca} \\
(\mathrm{ppm})\end{array}$ & $\begin{array}{c}\mathrm{Mg} \\
(\mathrm{ppm})\end{array}$ & $\begin{array}{c}\mathrm{Cu} \\
(\mathrm{ppm})\end{array}$ & $\begin{array}{c}\mathrm{Zn} \\
(\mathrm{ppm})\end{array}$ & $\begin{array}{c}\mathrm{Mn} \\
(\mathrm{ppm})\end{array}$ & $\begin{array}{c}\mathrm{Fe} \\
(\mathrm{ppm})\end{array}$ \\
\hline A1 & 196.5 & 2899 & 160 & 3.47 & 0.59 & 6.73 & 11.27 \\
\hline A2 & 127.40 & 3685 & 268 & 5.325 & 3.367 & 17.09 & 11.22 \\
\hline A3 & 141.50 & 3124 & 150 & 5.021 & 4.594 & 18.05 & 12.53 \\
\hline Mean $\pm \mathrm{Sd}$ & $155 \pm 36.5$ & $3236 \pm 404$ & $192 \pm 65.4$ & $4.60 \pm 0.99$ & $2.85 \pm 2.05$ & $13.9 \pm 6.27$ & $11.6 \pm 0.74$ \\
\hline B1 & 144.70 & 3378 & 298 & 2.963 & 2.607 & 15.77 & 25.95 \\
\hline B2 & 148.25 & 3256 & 350 & 3.35 & 2.21 & 18.95 & 27.81 \\
\hline Mean \pm Sd & $146 \pm 2.51$ & $3317 \pm 86.2$ & $324 \pm 36.7$ & $3.15 \pm 0.27$ & $2.4 \pm 0.28$ & $17.3 \pm 2.24$ & $26.8 \pm 1.31$ \\
\hline $\mathrm{C} 1$ & 38.80 & 3219 & 255 & 2.113 & 0.584 & 15.77 & 11.03 \\
\hline $\mathrm{C} 2$ & 25.90 & 3178 & 212 & 3.383 & 0.316 & 18.03 & 10.11 \\
\hline Mean \pm Sd & $19.4 \pm 27.4$ & $3198 \pm 28.9$ & $233 \pm 30.4$ & $2.74 \pm 0.89$ & $0.45 \pm 0.19$ & $16.9 \pm 1.59$ & $10.5 \pm 0.65$ \\
\hline D1 & 144.70 & 3040 & 165 & 2.963 & 2.607 & 15.77 & 25.95 \\
\hline D2 & 133.90 & 3130 & 159 & 3.621 & 2.918 & 18.05 & 15.65 \\
\hline Mean $\pm \mathrm{Sd}$ & $139 \pm 7.63$ & $3085 \pm 63.6$ & $162 \pm 4.24$ & $3.29 \pm 0.46$ & $2.76 \pm 0.21$ & $16.9 \pm 1.61$ & $20.8 \pm 7.28$ \\
\hline E1 & 144.70 & 3360 & 172 & 2.963 & 2.607 & 15.77 & 45.95 \\
\hline E2 & 172 & 3349 & 245 & 2.976 & 0.898 & 10.78 & 41.77 \\
\hline E3 & 152 & 3245 & 235 & 2.60 & 1.15 & 14.8 & 37.8 \\
\hline E4 & 182 & 3544 & 166 & 1.468 & 1.95 & 12.4 & 36.57 \\
\hline Mean $\pm \mathrm{Sd}$ & $162 \pm 17.2$ & $3374 \pm 124$ & $204 \pm 41.2$ & $2.50 \pm 0.71$ & $1.65 \pm 0.77$ & $13.4 \pm 2.26$ & $40.5 \pm 4.24$ \\
\hline $\mathrm{F} 1$ & 134 & 3256 & 145 & 2.4 & 0.67 & 3.8 & 15.5 \\
\hline F2 & 130 & 3140 & 155 & 2.6 & 0.58 & 3.5 & 14.6 \\
\hline Mean $\pm \mathrm{Sd}$ & $132 \pm 2.82$ & $3198 \pm 82.0$ & $150 \pm 7.07$ & $2.50 \pm 0.14$ & $0.63 \pm 0.06$ & $3.65 \pm 0.21$ & $15.0 \pm 0.63$ \\
\hline G1 & 209.50 & 3685 & 260 & 2.781 & 3.049 & 16.67 & 21.59 \\
\hline G2 & 177.7 & 3270 & 320 & 2.296 & 0.391 & 15.4 & 20.3 \\
\hline G3 & 188 & 3890 & 487 & 2.35 & 0.50 & 11.1 & 28.6 \\
\hline G4 & 200.80 & 3455 & 390 & 3.461 & 0.306 & 15.87 & 10.75 \\
\hline Mean \pm Sd & $194 \pm 14.0$ & $3575 \pm 270$ & $364 \pm 97.5$ & $2.72 \pm 0.53$ & $1.06 \pm 1.32$ & $14.7 \pm 2.49$ & $20.3 \pm 7.34$ \\
\hline $\mathrm{H} 1$ & 149.60 & 3456 & 205 & 1.81 & 0.269 & 4.99 & 24.17 \\
\hline $\mathrm{H} 2$ & 156 & 3241 & 210 & 3.41 & 1.78 & 5.32 & 32.65 \\
\hline H3 & 127 & 3120 & 235 & 2.32 & 0.349 & 9.49 & 16.484 \\
\hline $\mathrm{H} 4$ & 155.7 & 3675 & 284 & 1.67 & 1.22 & 10.6 & 18.20 \\
\hline H5 & 192.2 & 2989 & 310 & 2.87 & 0.331 & 6.47 & 10.42 \\
\hline H6 & 185 & 2886 & 183 & 2.37 & 2.341 & 14.4 & 54.6 \\
\hline H7 & 144.7 & 3080 & 283 & 2.96 & 2.607 & 15.7 & 45.95 \\
\hline H8 & 188.5 & 3568 & 334 & 2.99 & 0.647 & 5.50 & 20.46 \\
\hline H9 & 124 & 3380 & 312 & 3.87 & 2.792 & 7.93 & 37.59 \\
\hline Mean \pm Sd & $158 \pm 25.5$ & $3266 \pm 270$ & $262 \pm 55.6$ & $2.69 \pm 0.72$ & $1.37 \pm 1.03$ & $8.93 \pm 3.97$ & $28.9 \pm 14.7$ \\
\hline
\end{tabular}

Some species of Hermodactyloides and Scorpiris subgenera have great interspecific variations in morphology (particularly I. reticulata, I. histrio and I. persica), their taxonomic status and interspecific relationships are still disputed (Güner and Peşmen 1980, Goldblatt 2001, Güner and Duman 2007). Güner and Peşmen (1980) and Mathew (1989) have reorganised the morphological characters of subspecies of Hermodactyloides. According to this reorganisation, I. bakeriana is accepted as a species since it has 8 evident lines on leaves. Thus, based on the leaf charecteristics, Güner and Peşmen (1980) suggested that I. reticulata and I. bakeriana should be two independent species with close relationship. It is also evident statistically that I. reticulata and I. bakeriana are different species. Although a weak correlation is seen between $\mathrm{Mg}, \mathrm{Mn}$ and Fe values of $I$. reticulata and I. bakeriana, neither positive nor negative correlations are seen between other soil results $(\mathrm{p}>0.05)$. It is assumed that I. reticulata and I. bakeriana are independent species as they have different ecologic characteristics. The same state is seen in other Iris taxa in China by Yu et al. (2009) and in Jordan by Gabbiesh et al. (2006). 
I. histrio has been seperated into two subspecies by Mathew (1989) as subsp. histrio and subsp. aintabensis because of variations in leaf, perigon tube and segment measurements. Both subsp. histrio and subsp. aintabensis have limited distribution in Turkey. Some variation are seen in ecologic characteristics of both subsp. histrio and subsp. aintabensis. No correlation between salinity, organic matter, $\mathrm{pH}, \mathrm{N}, \mathrm{Ca}, \mathrm{Mg}, \mathrm{Cu}$ and $\mathrm{Mn}$ contents of soil samples of subsp. histrio and subsp. aintabensis ( $\mathrm{p}>0.05)$ have been observed. But positive correlation of the same with $\mathrm{P}, \mathrm{Zn}$ and $\mathrm{Fe}$ and negative correlation with $\mathrm{CaCO}_{3}$ were recorded $(\mathrm{p}<0.05)$ (Fig. 1). Since there is no significant correlation between soil analyses with the two subspecies, it is presumed that subsp. histrio and subsp. aintabensis are independent subspecies with close relationship. The same state is seen in other Iris taxa in China by Yu et al. (2009) and in Jordan by Gabbiesh et al. (2006).
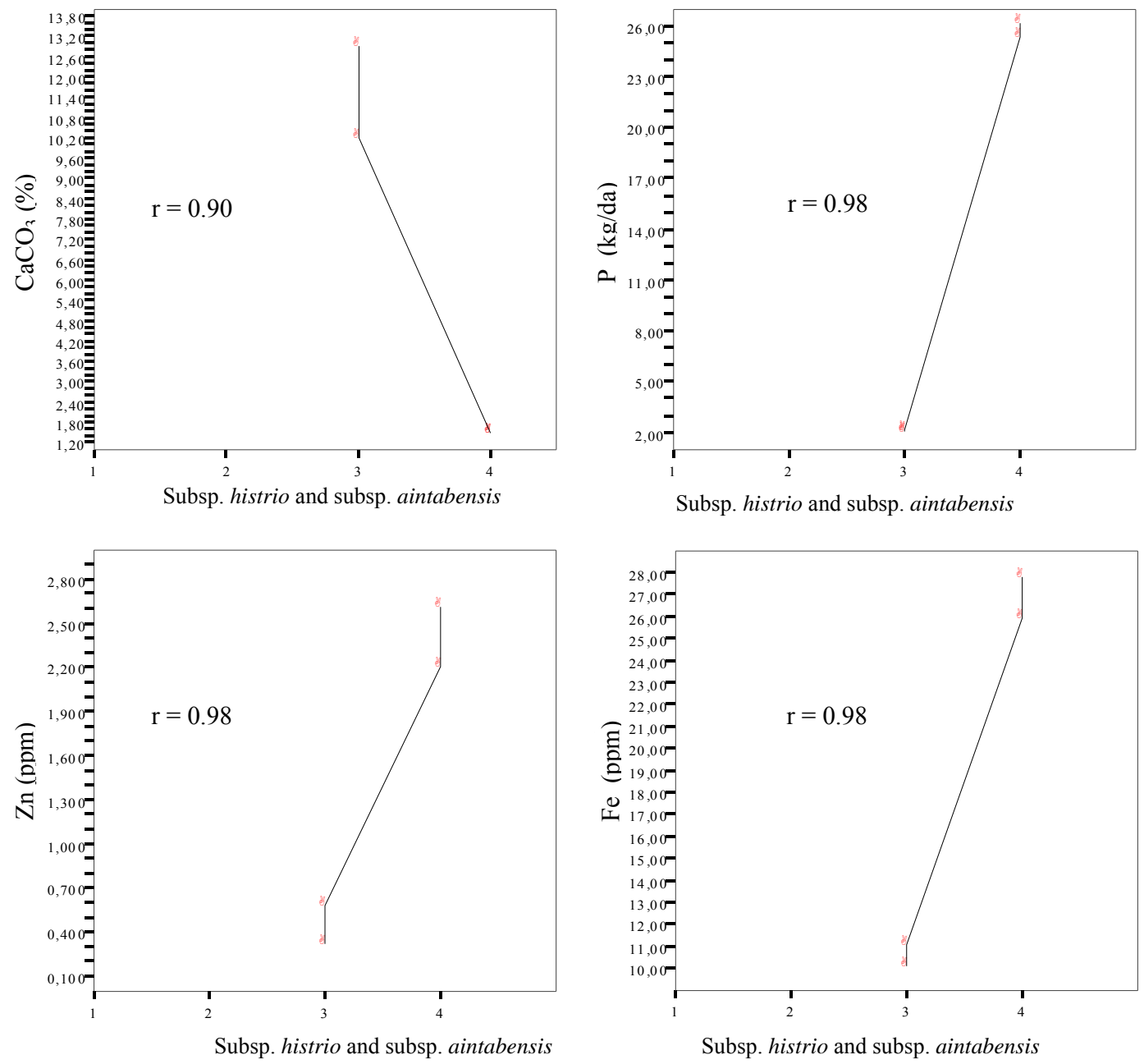

Fig. 1. Regression analysis graphs of two subsp. of Iris histrio with respect to soil $\mathrm{CaCO}_{3}, \mathrm{P}, \mathrm{Zn}$ and $\mathrm{Fe}$.

I. persica is widely distributed species of Scorpiris subgenus in Turkey and it shows large variation in terms of morphological, anatomical and palinological characteristic. Especially, the samples of this species distributed in some parts of Turkey is confused with I. galatica. Some 
problems remain in taxonomical assessment of I. persica. Güner and Peşmen (1980) have suggested that this species should be separated into subspecies. It has been found that I. persica is disributed in different soil types. Although statistically the positive and negative correlations have been observed between only pH, $\mathrm{CaCO}_{3}$ and $\mathrm{P}$ with I. persica $(\mathrm{p}<0.05)$ (Fig. 2) in some soils but no significant correlation was observed in some other sols. Thus, I persica should be divided into subspecies as Güner and Peşmen suggested above.
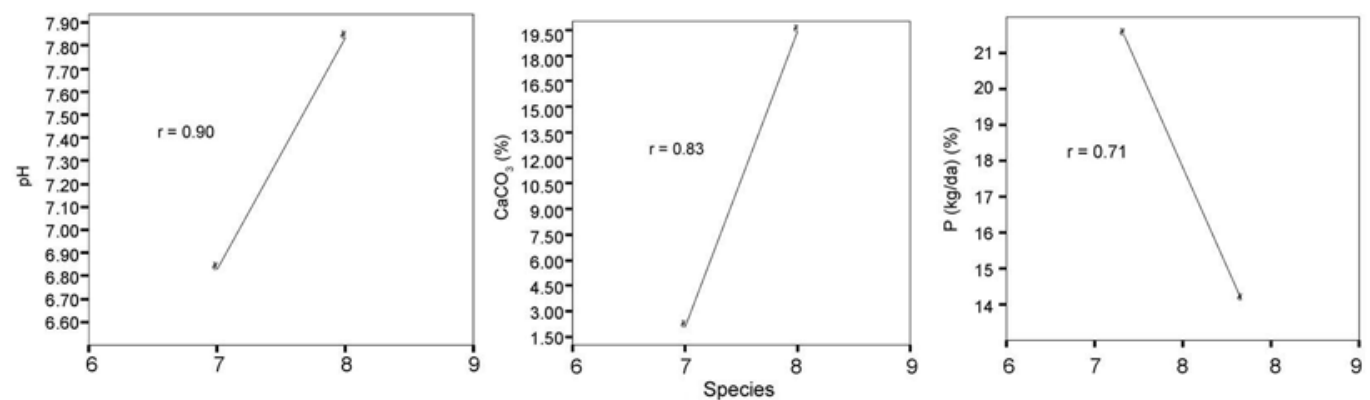

Fig. 2. Regression analysis graphs of Iris persica with respect to soil $\mathrm{pH}, \mathrm{CaCO}_{3}$ and $\mathrm{P}$.

Many geophytic plants are under threat in Turkey. Specially, natural habitats of endemic plants have been destroyed by numerous activities. This state of destruction has been affecting the biological diversity of the plants. From field observations, it was observed that race of some Iris species such as I. aucheri, subsp. aintabensis and I. pamphylica became endangered because of some activities such as dam construction, agriculture, grazing, fires, using pestitades and change in climate. Only, I. pamphylica and I. aucheri were reported in the VU (Vulnerable) category by Ekim et al. (2000) and Eker et al. (2008). Subsp. aintabensis should be included into VU category because of the reasons mentioned above.

Thus, it is neccessary to carry out careful field observations, anatomical studies, plastid and nuclear DNA sequencing on the taxa of both Hermodactyloides and Scorpiris subgenera to solve the intra and interspecific relationships between the taxa.

\section{References}

Anonymous 2010. Iris persica, TÜBIVES-Turkısh Plants Data Service.

Boşgelmez A, İI Boşgelmez, S Savaşçı and N Paslı 2001. Ecology II, Soil. Capital Klişe Press, Ankara. $98 \mathrm{pp}$.

Christensen KI and HA Akbulut 2004. Iris celikii (Iridaceae) a new species from north-eastern Turkey. Nord. J. Bot. 24: 207-210.

Eker I, M Koyuncu and H Akan 2008. The geophytic flora of Şanlıurfa province Turkey. Turk. J. Bot. 32: 367-380.

Ekim T, M Koyuncu, H Duman, Z Aytaç and N Adıgüzel 2000. Red Data Book of turkish plants (Pteridophyta and Spermatophyta). The Council of Protecting the Turkish Nature Press, Ankara. 96 pp.

Engin A, N Kandemir, G Şenel and M Özkan 1998. An autecological study on Iris pseudacorus L. (Iridaceae). Turk. J. Bot. 22: 335-340.

Gabbiesh AH, DS Hassawi and FU Afifi 2006. Determination of genetic diversity amoung Iris species using random amplified polymorphic DNA analysis. Biotech. 5(2): 173-179.

Goldblatt P 2001. Phylogeny and classification on the Iridaceae and the relationships of Iris. Ann. Bot. 1: $13-28$. 
Güner A and H Peşmen 1980. Taxonomical studies on some Iris L. species. Nature J. Fundamental Sci. 4(3): 25-37.

Güner A 1980. The observations on distribution areas of some Iris L. spesies in Turkey. TBTAK $7^{\text {th }}$ Science Cong., Aydin.

Güner A and H Duman 2007. A new Juno Iris from North-East Anatolia, Turkey. Turk J. Bot. 31: 311-315.

Iş̧1k S and F Candan 2009. Ecological properties of some Crocus taxa in Turkey. Afri. J. Biotech.8: 1895-1899.

Kaçar B 1996. Chemical analysis of plant and soil. Foundation of Education, Res. Dev. Publication, Ankara.

Kandemir N and A Engin 1998. An investigation morphologic, anatomic and ecologic on Iris nectarifera Güner (Iridaceae). pp. 283-299. 14 ${ }^{\text {th }}$ Ulusal Biology Cong., 7-10 Sep., 1998. Plant ecology and plant sytematic section, Samsun.

Kandemir N and Engin A 2000a. An autecological study on Iris histrioides Foster (Iridaceae) distributed in the Central Black Sea Region. Turk. J. Bot. 24: 347-354.

Kandemir N and A Engin 2000b. An autecological investigation on the endemic Iris galatica Siehe (Iridaceae). Ondokuz Mayıs University, Faculty of Arts and Sci., J. Sci. 1(1): 97-107.

Kandemir N 2003. An autecological study on the endemic Iris sari Schott ex Baker (Iridaceae). Herb J. Systematic Bot. 10(2): 31-51.

Kandemir N 2006. An investigation on the autecological endemic Iris taochia Woronow Ex Grossh. (Iridaceae) distributed in the North East Anatolia Region. Pak. J. Bio. Sci. 9: 2753-2760.

Kandemir N 2009. A morphology, anatomy and ecology of critically endangered endemic Crocus pestalozzae Boiss. (Iridaceae) in North-West Turkey. Bangladesh J. Bot. 38(2): 127-132.

Kandemir N and A Cansaran 2010. An autecological investigation on endemic Alkanna haussknechtii Bornm. (Boraginaceae) critically endangered in Turkey. Res. J. Agric. Biol. Sci. 6(5): 613-618.

Kutbay HG 1999. Top senesence in Sternbergia lutea (L.) Ker-Gawl. Ex Sprengel and Narcissus tazetta L. subsp. tazetta. Turk. J. Bot. 23: 127-131.

Malyer H 1983. The ecologic and karologic investigations on geophytes belonging to Liliaceae and Iridaceae family in Karaca-Mountain (Diyarbakır-Urfa). Sci. J. Nature 7(3): 279-288.

Mathew B 1984. Crocus. In: Flora of Turkey and the East Aegean Islands, Davis PH (Ed), pp. 413-438. Edinburg.

Mathew B 1989. A taxonomic revision of Iris Subgenus Hermodactyloides (Iridaceae) in plant taxonomy, Phytogeography and related subjects. Edinburg Univ. Press, Edinburg.

Satıl F and S Selvi 2007. An anatomical and ecological study of some Crocus L. (Iridaceae) taxa from the west part of Turkey. Acta Bot. Croat. 66: 25-33.

Yu FX, HQ Zhang, M Yuan and YH Zhou 2009. Karyotype studies on ten Iris species from Sichuan, China. Caryologia 62 (3): 253-260.

(Manuscript received on 19 May, 2011; revised on 12 October, 2011) 